\title{
PENGARUH FAKTOR SIKAP TERHADAP PENERIMAAN VAKSIN HPV PADA ORANG TUA MURID SEKOLAH DASAR DI KECAMATAN TELUK JAMBE TIMUR DAN TEGALWARU
}

\author{
Dedy Frianto*, Ahmad Dzulfikri Ashari, Surya Amal \\ Fakultas Farmasi, Universitas Buana Perjuangan Karawang, Karawang, Jawa Barat, \\ Indonesia. \\ *Penulis Korespondensi: dedyfrianto@ubpkarawang.ac.id
}

\begin{abstract}
ABSTRAK
Kanker serviks merupakan kanker yang paling sering terjadi pada wanita di dunia yang disebabkan oleh virus HPV (Human Papilloma Virus) terutama tipe 16 dan 18. Ada beberapa tindakan yang dapat dilakukan untuk menekan angka kejadian kanker serviks salah satunya dengan vaksinasi. Tujuan dari penelitian ini adalah untuk mengetahui gambaran sosio-demografi dan pengaruh sikap umum terhadap penerimaan orang tua pada vaksin HPV. Jenis penelitian yang digunakan adalah pendekatan kuantitatif secara analisis cross-sectional menggunakan kuisioner yang diadapatsi dari penelitian sebelumnya sudah dilakukan di Indonesia. Sampel dari penelitian ini adalah orang tua siswi kelas 5 dan 6 Sekolah Dasar yang jumlahnya dihitung menggunakan rumus slovin. Pengumpulan data berdasarkan hasil wawancara menggunakan kuisioner melibatkan 90 orang tua siswi sebagai responden dan menunjukkan hasil data sosio-demografi responden bahwa: agama responden Islam $(100 \%)$, pendidikan responden sebagain besar berpendidikan rendah (SD) $(54,44 \%)$, untuk pekerjaan meliputi ibu rumah tangga $(59,0 \%)$, swasta $(13,3 \%)$, buruh $(23,3 \%)$ dan guru $(4,4 \%)$. Untuk faktor sikap secara umum terhadap penerimaan vaksin HPV diperoleh hasil dengan skor kuisioner rata-rata 24,22 $\pm 8,36$ (menerima) dan skor rata-rata 27,66 $\pm 3,50$ (menolak) dari skor maksimal 30, hal ini menunjukkan bahwa dengan skor tingkat pengetahuan yang lebih tinggi $(27,66 \pm 3,50)$ responden tetap menolak vaksin dibandingkan dengan skor yang lebih rendah $(24,22 \pm 8,36$ ). Berdasarkan analisis uji Regresi Logistik menunjukan bahwa ,tidak terdapat hubungan yang bermakna antara faktor sikap umum tentang vaksin HPV terhadap penerimaaan orang tua siswi $\mathrm{p}=0,364$ ( $p$ value $>0,05$ ).
\end{abstract}

Kata kunci: Kanker serviks, Vaksin HPV, Terapi, Penerimaan 


\title{
THE INFLUENCE OF ATTITUDE FACTORS ON RECEPTION HPV VACCINE IN PARENTS OF PRIMARY SCHOOL STUDENTS IN KECAMATAN TELUKJAMBE TIMUR AND TEGALWARU
}

\begin{abstract}
Cervical cancer is the most common cancer in women in the world which is caused by the HPV (Human Papilloma Virus), especially types 16 and 18. Several actions can be taken to reduce the incidence of cervical cancer, one of which is vaccination. The purpose of this study was to determine the socio-demographic picture and the effect of general attitudes on parental acceptance of the HPV vaccine. The type of research used is a quantitative approach with cross-sectional analysis using a questionnaire adapted from previous research conducted in Indonesia. The sample of this study was the parents of grade 5 and 6 elementary school students whose numbers were calculated using the Slovin formula. Data collection is based on the results of interviews using a questionnaire involving 90 parents of students as respondents and shows the results of the socio-demographic data of respondents that the religion of the respondents is Islam (100\%), most of the respondents have low education (SD) (54.44\%), includes housewives $(59.0 \%)$, private sector (13.3\%), laborers $(23.3 \%)$ and teachers (4.4\%). For general attitude factors towards the acceptance of the HPV vaccine, the results were obtained with an average questionnaire score of $24.22 \pm 8.36$ (accept) and an average score of $27.66 \pm 3.50$ (reject) from a maximum score of 30 , this shows that with a higher knowledge level score (27.66 \pm 3.50$)$, respondents still rejected the vaccine compared to a lower score (24.22 \pm 8.36). Based on the Logistic Regression test analysis, it shows that there is no significant relationship between general attitudes about the HPV vaccine and the acceptance of the parents of students $\mathrm{p}=$ 0.364 ( $\mathrm{p}$ value $>0.05$ ).
\end{abstract}

Keywords: Cervical cancer, HPV vaccine, Therapy, Acceptance

\section{PENDAHULUAN}

Kanker serviks merupakan salah satu jenis kanker yang paling sering terjadi pada wanita di dunia. Angka kematian di beberapa negara bekembang mencapai 270.000 kasus yang terjadi pada wanita karena kanker serviks (WHO, 2104). Penyakit ini menempati urutan ketiga di Asia dan merupakan salah satu faktor penyebab kematian pada wanita (Haryani et al., 2016). Data yang diperoleh dari Sistem Informasi Rumah Sakit Hasan Sadikin Bandung, Kabupaten Karawang menempati peringkat kelima dengan angka rujukan pasien kanker serviks yang cukup tinggi yaitu sebesar 55\% (RSUP Dr. Hasan Sadikin Bandung, 2015). Tingkat kerentanan genetik dari seseorang dapat menyumbang kurang dari $1 \%$ dari angka kasus kanker serviks (Murillo et al., 2016). Sebagain besar penyebab kanker serviks adalah virus HPV (Human Papilloma Virus) tipe 16 dan 18 (Andrijono et al., 2013).

Upaya pencegahan kanker serviks antara lain dapat dilakukan dengan rutin melakukan pengontrolan perilaku seksual baik diri sendiri dan pasangan, memperhatikan jenis kontrasepsi yang akan digunakan, membatasi merokok, 
dan mengkonsumsi makanan yang sehat dan bergizi (Gayatri dan Nurachmah, 2003). Pada umumnya terapi untuk kanker dapat dilakukan dengan tiga cara utama antara lain tindakan operasi, radiasi dan kemoterapi. World Health Organization (WHO) merekomendasikan pemberian vaksin dianjurkan sejak masih remaja usia 9-13. Berdasarkan data dari beberapa Rumah Sakit di Jakarta Angka kelangsungan hidup (Survival rate) pasien kanker serviks selama 5 tahun berturutturut menunujukan hasil sebesar 35-54\%. Banyak faktor seseorang untuk menerima vaksin, diantaranya adalah faktor keyakinan, pengetahuan, dan sikap. Sikap umum terhadap vaksin dapat berpengaruh terhadap seseorang untuk menerima atau menolak vaksin, Penerimaan merupakan bagian dasar untuk seseorang dapat menerima kenyataan dalam hidupnya baik pengalaman baik ataupun pengalaman buruk seseorang (Kubler Ross, 1969).

Biaya pengobatan yang tinggi, tidak menjamin survival rate dan kesembuhan pasien kanker serviks, oleh karena itu perlu dilakukan tindakan pencegahan berupa vaksin HPV. Banyak faktor yang memengaruhi orang tua untuk menerima anaknya untuk divaksin, salah satunya adalah faktor sikap umum terhadap vaksin. Pada penelitian ini peneliti ingin mengetahui pengaruh faktor sikap umum pada vaksin terhadap penerimaan orang tua terhadap vaksin HPV.

\section{METODE PENELITIAN}

Penelitian ini merupakan penelitian dengan pendekatan secara kuantitatif berupa analisis cross-sectional, dengan mengajukan pertanyaan berupa kuisioner yang diadopsi dari penelitian terdahulu terhadap responden, serta responden telah bersedia dan mengisi informed concent. Target responden dalam penelitian yang dilakukan ini ditentukan menggunakan metode area sampling dengan menentukan frame area di kabupaten karawang, kemudian menentukan sekolah yang yang menjadi target secara acak, semua orang tua siswi kelas 5 dan 6 di SD yang telah dipilih menjadi populasi yang akan dijadikan responden pada penelitian ini. Sampel dari penelitian merupakan orang tua yang memiliki anak perempuan yang sedang duduk di bangku kelas 5 dan 6 Sekolah Dasar yang termasuk dalam populasi penelitian. Pengambilan data menggunakan kriteria inklusi sebagai berikut:

a. Sekolah Dasar yang mewakili kecamatan yang telah dipilih

b. Orang tua siswi Sekolah Dasar kelas 5 dan kelas 6 yang bersedia menjadi responden.

perhitungan sampel 
Karena populasi dalam penelitian ini diketahui maka dalam penelitian ini Slovin (Ridwan, 2005):

$$
\mathrm{n}=\frac{N}{N d^{2}+1}
$$

Keterangan

$\mathrm{n}=$ jumlah sampel

$\mathrm{N}=$ Jumlah Populasi

$\mathrm{d}=$ derajat ketetapan

Penelitian ini menggunakan tingkat kepercayaan 95\%. Populasi yang diperoleh di SD IT Abata, SDN Cintawargi 1, SD IT Alam Amani dan
SD IT Nurul Qur'an yaitu sebanyak 114 responden, setelah dihitung menggunakan rumus slovin maka diperoleh jumlah sampel:

$$
\begin{aligned}
& \mathrm{n}=\frac{N}{N d^{2}+1} \\
& \mathrm{n}=\frac{114}{114 \cdot(0,5)^{2}+1} \\
& \mathrm{n}=\frac{114}{114 \cdot 0,0025+1} \\
& \mathrm{n}=\frac{114}{1,285} \\
& \mathrm{n}=89 \text { responden }
\end{aligned}
$$


HASIL PENELITIAN

Sosio-Demografi Responden

Tabel 1. Data Sosio-Demografi Responden

\begin{tabular}{|c|c|c|c|}
\hline No & Sosio-demografi & $\begin{array}{c}\text { Jumlah } \\
(n=90)\end{array}$ & $\begin{array}{l}\text { Tanggapan } \\
(\%)\end{array}$ \\
\hline \multirow[t]{2}{*}{1} & Agama & & \\
\hline & Islam & 90 & 100 \\
\hline \multirow[t]{4}{*}{2} & Pendidikan & & \\
\hline & Tinggi (Universitas) & 16 & 17,7 \\
\hline & Sedang (SMP-SMA) & 25 & 27,7 \\
\hline & Rendah ( SD) & 49 & 54,4 \\
\hline No & Sosio-demografi & Jumlah $(n=90)$ & $\begin{array}{l}\text { Tanggapan } \\
(\%)\end{array}$ \\
\hline \multirow[t]{5}{*}{3} & Penghasilan & & \\
\hline & $<\mathrm{UMR}$ & 13 & 14,44 \\
\hline & $=\mathrm{UMR}$ & 0 & 0 \\
\hline & > UMR & 7 & 7,77 \\
\hline & Tidak menjawab & 70 & 77,77 \\
\hline \multirow[t]{5}{*}{4.} & Pekerjaan & & \\
\hline & Ibu Rumah Tangga & 53 & 59,0 \\
\hline & Swasta & 12 & 13,3 \\
\hline & Buruh & 21 & 23,3 \\
\hline & Guru & 4 & 4,4 \\
\hline \multirow[t]{4}{*}{5} & Usia & & \\
\hline & 11 tahun & 49 & 54,4 \\
\hline & 12 tahun & 31 & 34,4 \\
\hline & 13 tahun & 10 & 11,1 \\
\hline \multirow[t]{5}{*}{6} & Kanker & Jumlah $(n=90)$ & $\begin{array}{l}\text { Tanggapan } \\
(\%)\end{array}$ \\
\hline & $\begin{array}{l}\text { Keluarga dekat yang menderita kanker } \\
\text { serviks }\end{array}$ & & \\
\hline & Tidak menjawab & 0 & 0 \\
\hline & $\mathrm{Ya}$ & 1 & 1,1 \\
\hline & Tidak & 89 & 98,8 \\
\hline
\end{tabular}




\section{Analisis Regresi Logistik}

Tabel 2. Penaksiran Analisa Regresi Logistik Variabel Pendidikan

\begin{tabular}{lllcr}
\hline No & Variabel & Sig. & Exp $(\mathbf{B})$ & $\mathbf{9 5 \%}$ CI \\
\hline 1 & Tinggi dan rendah & 0,20 & 0,260 & $0,812-0,812$ \\
2 & Rendah dan Menengah & 0,609 & 0,479 & $0,209-8.009$ \\
3 & Menengah dan Tinggi & 0,90 & 0,139 & $0,014-1,356$ \\
\hline
\end{tabular}

Tabel 3. Analisa Regresi Logistik Variabel Sikap Umum Terhadap Penerimaan Vaksin HPV

\begin{tabular}{cccccc}
\hline No. & Variabel & Mean & Odd Ratio & CI95\% & P value \\
\hline 1 & Faktor sikap & & 2,639 & $0,922-1,249$ & 0,364 \\
& & & & & \\
& Menerima & $24,22 \pm 8,36$ & & & \\
& Menolak & $27,66 \pm 3,50$ & & & \\
\hline
\end{tabular}

\section{PEMBAHASAN}

Hasil penelitian diperoleh data sebanyak 90 orang responden $(100 \%)$ beragama Islam. Dari data tersebut menunjukan mayoritas agama responden beragama Islam, hal ini sejalan dengan penelitian yang dilaukan oleh Uus Sugiana menyampaikan bahwa mayoritas masyarakat karawang memeluk agama Islam (Sugiana et al., 2013). Jika dilihat dari tingkat pendidikan responden sebanyak 49 orang $(54,4 \%)$ masuk dalam tingkat pendidikan rendah, sedangkan di Kabupaten Karawang pada tahun 2015 menunjukan sebesar hampir 50\% penduduk di Kabupaten Karawang termasuk dalam tingkat pendidikan dasar yaitu SD sederajat, data tersebut menunjukan hasil dominasi dalam segi pendidikan (Pemkab Karawang, 2018).
Dari segi tingkat penghasilan responden sebesar 72,2\% tidak menjawab, hal tersebut dikarenakan mayoritas responden berprofesi sebagai ibu rumah tangga yaitu sebanyak 53 orang reponden $(59,0 \%)$ sehingga rata-rata responden tidak mempunyai penghasilan dan tidak berkenan menyampaikan penghasilan keluarga . dilihat dari usia responden menunjukan sebesar $(54,4 \%)$ berusia 11 tahun, $34,4 \%$ berusia 12 tahun dan $(11,1 \%)$ berusia 13 tahun, hal tersebut sesuai dengan rentang usia yang telah di tentukan yaitu 9 sampai 13 tahun.

Pada tabel 2. menunjukan bahwa variabel independen (pendidikan) memiliki nilai $P$ value Sig $0,20>0,05$, sehingga menerima $\mathrm{H} 0$ atau yang berarti pendidikan pada tingkat tinggi dan rendah memberikan pengaruh parsial yang tidak 
signifikan terhadap penerimaan vaksinasi HPV. Berdasarkan data hubungan antara tingkat pendidikan rendah dan menengah menunjukan nilai $P$ value $S i g$ 0,609>0,05, sehingga menerima $\mathrm{H} 0$ atau yang berarti pendidikan pada tingkat tinggi dan rendah memberikan pengaruh parsial yang tidak signifikan terhadap penerimaan vaksinasi HPV, sedangkan dari segi tingkat pendidikan menengah dan tinggi menunjukan nilai $P$ value Sig 0,90>0,05, sehingga menerima $\mathrm{H} 0$ atau yang berarti pendidikan pada tingkat tinggi dan rendah memberikan pengaruh parsial yang tidak signifikan terhadap penerimaan vaksin HPV. Hasil penelitian ini sejalan dengan penelitian yang dilakukan oleh Nursalam yang menyatakan bahwa Pendidikan sangat mempengaruhi seseorang dalam memotivasi untuk siap berperan serta dalam penerimaan vaksin HPV (Nursalam, 2009). Menurut pendapat peneliti, pada hasil penelitiaan tentang hubungan antara pendidikan dan penerimaan orang tua menunjukan tidak ada hubungan antar variabel tersebut. Oleh karena itu perlu dilakukan kegiatan berupa edukasi yang mampu memberikan pemahaman mengenai vaksin HPV, sehinga dapat menstimulansi adanya sikap yang positif terhadap orang tua siswa.

Pada tabel 3. menunjukan data variabel sikap umum responden atau orang tua terhadap penerimaan vaksin HPV di Kecamatan Telukjambe dan Tegalwaru dengan nilai signifikansi sebesar 0,364 nilai signifikansi tersebut lebih dari 0,05 yang artinya variabel tersebut tidak berpengaruh pada penerimaan orang tua terhadap vaksinasi HPV dengan nilai odds ratio sebesar 2,639, dari tabel dapat dilihat diperoleh nilai rata-rata sikap orang tua terhadap vaksin HPV, kelompok responden yang menerima mendapat total skor sebesar 24,22 dan yang menolak sebesar 27,66, hal ini menunjukan bahwa nilai sikap yang semakin tinggi $(27,66 \pm 3,50)$ tetap menolak diberikan vaksin HPV dibandingkan dengan kelompok yang menerima dengan nilai skor sikap yang lebih rendah (24,22 $\pm 8,36)$. Meskipun nilai sikap umum cukup tinggi namun responden masih menolak vaksin HPV karena masih kurangnya informasi tentang vaksin HPV. Selain itu dari data kuisioner yang diperoleh dari data sosiodemografi menunjukan lebih dari $95 \%$ responden tidak memiliki keluarga yang memiliki riwayat menderita penyakit kanker serviks sehingga pola pikir responden kurang mendukung adanya vaksin HPV. Hal ini sejalan dengan penelitian Rahmawati., yang menunujukan hasil sebesar 97,7\% pengaruh keluarga sangat berpengaruh 
terhadap keputusan untuk divaksin HPV (Rahmawati, 2013).

\section{KESIMPULAN}

Berdasarkan hasil penelitian tentang peneriman orang tua terhadap penerimaaan vaksinasi HPV dapat ditarik kesimpulan dari data sosio-demografi responden menunjukan bahwa semua Responden beragama Islam, pendidikan responden mayoritas tingkat pendidikan rendah (Sekolah Dasar), dan pekerjaan mayoritas ibu rumah tangga. Faktor sikap umum terhadap vaksin tidak berpengaruh secara signifikan terhadap penerimaan orang tua terhadap vaksin HPV dengan menggunakan analisis statistik regresi logistik.

\section{DAFTAR PUSTAKA}

Andrijono, Purwoto, G., Sekarutami, SM., Handjari, DR., Primariadewi, Nuhonni, SA., dan Octovia, LI. Panduan Penatalaksanaan Kanker Serviks. Cancer, 2013, 8(1): 33-39.

Gayatri, D., dan Nurachmah, E. Peluang Ketahanan Hidup 5 Tahun Pasien Kanker Serviks Di RSUPN Dr. Cipto Mangunkusumo dan RSK Dharmais, Jakarta, 2002. Jurnal Keperawatan Indonesia, 2003, 7:17-21.

Haryani, S., Defrin, D., dan Yenita, Y. Prevalensi Kanker Serviks Berdasarkan Paritas di RSUP. Dr. M. Djamil Padang Periode Januari 2011- Desember 2012. Jurnal Kesehatan Andalas, 2016, 5(3): 647-652.
Kübler-Ross, E. 1969. On Death and Dying. Routledge. New York: The Macmillan Company.

Murillo, R., Herrero, R., Sierra, MS., and Forman, D. Cervical cancer in Central and South America: Burden of disease and status of disease control. Cancer Epidemiol, 2016, 44(Suppl 1): 121-130.

Nursalam. 2009. Proses dan Dokumentasi Keperawatan: Konsep dan Praktik. Jakarta: Salemba Medika.

Pemerintah Kabupaten Karawang. (2018). Laporan Kinerja Pemerintah Kabupaten Karawang. Halaman 48.

Rahmawati. 2013. Faktor-Faktor yang Mempengaruhi Kelengkapan Imunisasi Dasar di Kelurahan Krembangan Utara Kota Surabaya Sebagai Upaya Pencegahan Penyakit. Skripsi. Fakultas Kesehatan Masyarakat, Universitas Airlangga.

Ridwan. 2005. Metode dan Teknik Penyusunan Tesis. Bandung: CV Alfa Beta.

RSUP Dr. Hasan Sadikin Bandung. 2015. Standar Prosedur Operasional: Early Warning Score. Bandung: RSUP Dr. Hasan Sadikin.

Sugiana, U., Koswara, D., dan Haerudin, D. Tradisi Ngayun Di Kecamatan awamerta Kabupaten Karawang (Kajian Struktural-Semiotik). Lokabasa, 2013, 5(1): 104-110.

World Health Organization. 2014. Comprehensive Cervical Cancer Control. Geneva, 366-378. 